\title{
Immune responses of phenoloxidase and superoxide dismutase in the manila clam Venerupis philippinarum challenged with Vibrio tapetis - Part I: Spatio-temporal evolution of enzymes' activities post-infection
}

\author{
Le Bris Cedric ${ }^{1,}{ }^{*}$, Richard Gaelle ${ }^{1}$, Paillard Christine ${ }^{1}$, Lambert Christophe ${ }^{1}$, Seguineau Catherine ${ }^{1}$, \\ Gauthier Olivier ${ }^{1}$, Pernet Fabrice ${ }^{2}$, Guerard Fabienne ${ }^{1}$
}

\footnotetext{
1 UMR 6539 CNRS UBO IRD IFREMER, LEMAR, IUEM, UBO, Institut Universitaire Européen de la Mer, Université de Bretagne Occidentale, Technopôle Brest-Iroise, Rue Dumont d'Urville, 29280 Plouzané, France

2 UMR 6539 CNRS UBO IRD IFREMER, LEMAR, IUEM, UBO, Ifremer, Laboratoire de Physiologie des Invertébrés, Technopôle Brest-Iroise BP 70 29280, Plouzané, France
}

*Corresponding author : Cédric Le Bris, email address : cedric lebris@yahoo.fr

\begin{abstract}
:
Manila clams, Venerupis philippinarum (Adams and Reeve, 1850), were experimentally challenged with two Vibrio tapetis strains: CECT4600T, the causative agent of Brown Ring Disease (BRD); and LP2 supposedly non-pathogenic in V. philippinarum. Changes in phenoloxidase (PO) and superoxide dismutase (SOD), two major enzymes involved in immunity, were studied in two tissues, the mantle and hemolymph for 30 days after infection in the extrapallial cavity. Bacterial infection in V. philippinarum resulted in modulation of $\mathrm{PO}$ and SOD activities that was both tissue- and time-dependent. A response at early times was detected in the mantle and was associated with significant increases in PO and SOD activities in LP2- and CECT4600T-challenged clams 36h post injection. This first response in the mantle could be explained by the proximity to the injection region (extrapallial cavity). In the hemolymph the response occurred at later times and was associated with an increase in PO activity and a decrease in SOD activity. As hemolymph is a circulating fluid, this response delay could be due to an "integration time" needed by the organism to counteract the infection. Injections also impacted PO and SOD activities in both tissues and confirmed a difference in pathogenicity between the two $\mathrm{V}$. tapetis strains.
\end{abstract}




\section{Highlights}

- Venerupis philippinarum infection with two Vibrio tapetis strains (CECT4600 and LP2). Modulation of $\mathrm{PO}$ and SOD activities after infections was tissue- and time-dependent. PO and SOD activities increased $36 \mathrm{~h}$ post injection in the mantle. $\$ P O$ activity increased and SOD activity decreased in later times in hemolymph. PO and SOD activity levels confirmed the strain pathogenicity difference.

Keywords: Venerupis philippinarum, Vibrio tapetis, Brown Ring Disease, Immunity, Phenoloxidase, Superoxide Dismutase

\section{Introduction}

The Manila clam, Venerupis philippinarum (Adams and Reeve, 1850) was introduced to France from the USA in 1972 for aquaculture purposes, because its growth is faster than that 
of the European clam Venerupis decussata (Linnaeus, 1758) [1]. Since 1987, the species has been affected by brown ring disease (BRD) caused by the pathogenic gram-negative bacterium Vibrio tapetis [2]. BRD is diagnosed by the formation of a brown deposit of conchiolin at the edge of the mantle on the inner shell of the clam [3]. During the development of the disease, the bacterium first colonizes the periostracal lamina, and then in some conditions (lesions, starvation) tissues and finally moves into the circulatory system, leading to a systemic infection and the organism's death; the effects of BRD on Manila clams have been reviewed by Paillard [4]. BRD has decimated clam populations, first in Brittany (France) and spreading along French and European coasts [3]. Since the isolation of the pathogenic bacterium (V. tapetis CECT4600 ${ }^{\mathrm{T}}$ ) in the Manila clam from Landeda (Brittany, France) in 1990 [5, 6], around 40 different V. tapetis strains have been isolated in various mollusks and fishes in France [5], England [7, 8], Spain [9], Norway [10], Scotland [8] and Japan [11]. Pathogenicity of the majority of these strains has been evaluated, and V. tapetis $\mathrm{CECT}_{4600^{\mathrm{T}}}$ was shown to be the most pathogenic strain to $V$. philippinarum $[12,13]$. To prevent mortalities caused by BRD it is necessary to understand both the mechanisms by which the pathogenic bacteria act and equally how the host immune system functions. Many studies have been conducted on clam immune responses during bacterial infection, and it has been shown that the occurrence of $V$. tapetis in the hemolymph leads to a decrease in size and complexity of granulocytes [14] and to a loss of hemocyte adhesion capacities because, these cells become rounded and lose their pseudopodia [12]. More recently it was demonstrated that $V$. tapetis occurrence in hemolymph significantly increases nitric oxide production in a dosedependent manner [15]. Most of the studies on $V$. philippinarum immune response to $V$. tapetis infection have focused on cellular immunity, in particular hemocytes [7, 16-19]. However, invertebrate immunity can be divided into cellular and humoral immune response [20]. Hence, host immunity, and its potential defense capability against pathogen agents, could also be investigated through the nature and activity of endogenous enzymes [21]. Phenoloxidase (PO), which is one of these humoral immune enzymes, is often monitored because of its key role in invertebrate immune systems and especially in the activation of the melanization cascade [22]. In fact POs (E.C. 1.14.18.1, E.C. 1.10.3.1 and E.C. 1.10.3.2) oxidize phenolic compounds into corresponding quinones and then into melanin and its derivatives [23, 24] which have fungistatic, bacteriostatic and antiviral properties [25]. For example, in the oyster Saccostrea glomerata, a negative correlation was found between PO 
activity level and the level of infection by Marteilia sydneyi which is responsible for QX disease [26]. Indeed, a QX resistance breeding program developed along the Australian East coast has selected oysters with enhanced PO activity [27]. PO activity in $V$. philippinarum hemolymph has been biochemically characterized [28, 29] but variations in PO after infection has, to date, never been followed. Superoxide dismutase (SOD) (E.C. 1.15.1.1), like PO, is an oxidoreductase that contributes towards innate immunity by preventing the accumulation of Reactive Oxygen Species (ROS) in the organism, particularly superoxide anions $\left(\mathrm{O}_{2}{ }^{-}\right)$. In marine bivalves, ROS are generated in larger proportions as the organism is exposed to biotic challenges such as Vibrio extracellular products [30, 31]. ROS are known to exhibit antimicrobial properties but overconcentration can lead to cellular damages: the antioxidant paradox [32]. In order to control the cell redox status, antioxidant enzymes are recruited to diminish ROS concentration. Intracellular SOD gene expression analyses performed in Manila clams infected with Vibrio species (V. anguillarum, V. tapetis) showed timedependent variations over short periods (96 hours maximum) [33, 34], suggesting the regulation of this protein and its involvement in innate immunity of $V$. philippinarum. Nevertheless, SOD has not been studied biochemically in Vibrio-challenged clams so far, and it is interesting to focus on biological activities of PO and SOD over longer periods (up to 30 days after injection) since BRD symptoms require time to develop after infection.

Thus, the aim of this study was to investigate the effects $V$. tapetis infection on immune enzymatic activities in $V$. philippinarum. Clams were infected with two different $V$. tapetis strains and monitored for 30 days after infection. More precisely, our study compared PO and SOD immune activity, in different compartments, of clams injected with two different $V$. tapetis strains, considered more or less virulent, or with Sterile Sea Water (SSW) as a control.

\section{2-Materials and methods}

\section{2-1-Biological material and acclimation procedure}

Around 600 adult $V$. philippinarum, $39.80 \mathrm{~mm} \pm 2.60$ (SD) long were collected from Ile Tudy, Brittany (France), by SATMAR (Aquaculture Company) in October 2012 and transferred to the laboratory. These clams were divided between 9 aerated 75L tanks at $15.3 \pm$ $0.64^{\circ} \mathrm{C}$ and acclimated for one week before injections. The 9 tanks correspond to the three conditions (Two V. tapetis strains and one control) made in triplicate. 


\section{2-2-Bacterial strains}

For the bacterial challenge experiments, two $V$. tapetis strains were used: $V$. tapetis $\mathrm{CECT}_{4000^{\mathrm{T}}}$ (also known as CIP 104856) which was isolated from diseased $V$. philippinarum from Brittany, France in 1990 [6, 35]; and LP2, isolated from the fish Symphodus melops in Norway in 1999 [10], and previously considered as non-pathogenic to V. philippinarum after in vivo pallial cavity inoculation or in vitro biotests $[12,13]$. These strains were grown in Zobell's medium overnight at $18^{\circ} \mathrm{C}$ and bacterial solution concentrations were determined by spectrophotometry at $490 \mathrm{~nm}\left([\mathrm{C}]=\right.$ O.D. $\left.\times 1.3 \times 10^{9}-3.6 \times 10^{7}\right)$.

\section{2-3-Experimental injections}

Before experimental injections, 30 clams were sacrificed in order to check their asymptomatic status. Twelve hours before injections, animals were removed from their tank and only replaced in $15^{\circ} \mathrm{C}$ sea water just before the injections to facilitate their opening. Experimental infections were carried out by injecting $100 \mu \mathrm{L}$ of $V$. tapetis suspension $\left(10^{6} \mathrm{CFU} \cdot \mathrm{mL}^{-1}\right)$ per individual into the extrapallial cavity with sterile needles $(25 \mathrm{G} 0.5 \times 16 \mathrm{~mm})$ fitted onto $1 \mathrm{~mL}$ sterile syringes. The needle was introduced in the extrapallial cavity under the mantle. Control clams were inoculated, in the same manner, with $100 \mu \mathrm{L}$ of sterile sea water (SSW) in the extrapallial cavity. After the injections, animals were kept for 6 hours out of sea water before being put back into their aerated tanks to keep the bacteria and favor their colonization to the periostracal lamina.

\section{2-4-Fluid and tissue collection}

Individuals were sampled before the injections (T0), and at 36 hours, 72 hours, 7 days, 14 days and 30 days post-injection (p.i.). On each sampling occasion 5 individuals were sampled from each individual tank, yielding a total of 15 individuals per condition at every sampling time.

\section{2-4-1- Hemolymph and extrapallial fluid collection}

Hemolymph of each sampled clam was withdrawn from the adductor muscle as described by Auffret \& Oubella [36]. Collected hemolymph was centrifuged at $785 \mathrm{~g}$ for 10 minutes at $4^{\circ} \mathrm{C}$, to separate the hemocytes from the serum. The resulting serum was stored at $-80^{\circ} \mathrm{C}$ until enzymatic and protein assays. After hemolymph collection, the Extrapallial Fluid (EF) was collected from each valve by opening the valves and inserting a second sterile needle $(25 \mathrm{G}$ 
$1270.5 \times 16 \mathrm{~mm}$ ), fitted on a sterile syringe, between the mantle and shell in the sinusal and

128 central compartments. The EF was then centrifuged at $785 \mathrm{~g}$ for 10 minutes at $4{ }^{\circ} \mathrm{C}$ to separate

129 the cellular and acellular fractions (serum). This serum was stored at $-80^{\circ} \mathrm{C}$ until enzymatic

130 and protein assays.

$131 \quad$ 2-4-2-Tissue collection and protein extraction

132 Both right and left mantle were dissected and immediately frozen in liquid nitrogen. Samples

133 were stored at $-80^{\circ} \mathrm{C}$ until being powderized in a Retsch MM 400 blender by grinding with

134 liquid nitrogen. The powder obtained was stored at $-80^{\circ} \mathrm{C}$. Before use, samples were 135 resuspended in $500 \mu \mathrm{L}$ of lysis buffer [37]. The resuspended powder was then homogenized 136 using Ultra-Turrax (Modele PRO 200) and centrifuged at $10000 \mathrm{~g}$ for 45 minutes at $4^{\circ} \mathrm{C}$.

137 Enzymatic and protein assays were carried out on the resulting supernatant.

\section{$138 \quad$ 2-5-Protein determination}

139 The total protein content of $V$. philippinarum serum, extrapallial fluid and mantle lysate 140 supernatant was determined by the Bradford method [38] using BioRad Protein Assay Dye 141 Reagent Concentrate (BioRad France) and bovine serum albumin (BSA) as the protein 142 standard.

\section{$143 \quad$ 2-6-Enzyme activity assays}

\section{$144 \quad$ 2-6-1-Phenoloxidase assays}

145 PO activity was assayed spectrophotometrically in 96-well microplates (Greiner 96-F-

146 bottom), by recording the formation of quinones according to the protocol of Le Bris et al. 147 [29]. Briefly, $50 \mu \mathrm{L}$ of Tris- $\mathrm{HCl}$ buffer $(0.10 \mathrm{M}, \mathrm{pH} 8.0)$ were added to $50 \mu \mathrm{L}$ of enzymatic 148 solution (Hemolymph and EF serum and grinded mantle supernatant). This mixture was 149 incubated for 10 minutes at $25^{\circ} \mathrm{C}$, before $100 \mu \mathrm{L} 0.04 \mathrm{M} \mathrm{L}-3,4$-dihydroxyphenylalanine (L150 DOPA) were added to each well. L-DOPA is common substrate for the three PO subclasses. 151 PO activity was then monitored for 30 minutes following the increase of absorbance at $492 \mathrm{~nm}$ 152 (using POLARstar Omega - BMG Labtech). At the same time, the spontaneous oxidation of 153 L-DOPA was measured and the values obtained were subtracted from the test values. The PO 154 specific activities in international unit (U.I.) per milligram of total protein were calculated as 155 follows: 
156 PO specific activity (U.I.mg protein $\left.{ }^{-1}\right)=\left(\Delta\right.$ A. $\min ^{-1} \times$ dilution factor) $/$ Total protein 157 concentration

158 Where $\Delta \mathrm{A} \cdot \mathrm{min}^{-1}$ is the value of the increment of absorbance per minute, dilution factor is the

159 sample's factor of dilution, and total protein concentration is the sample's protein

160 concentration.

161

162

163

164

165

166

167

168

169

170

171

172

173

174

175

176

177

178

179

180

181

182

183

184

185

\section{2-6-2-Superoxide dismutase assays}

Total superoxide dismutase (SOD: EC 1.15.1.1) activity was assayed spectrophotometrically in 96-well microplates (Greiner 96-F-bottom) by an indirect method based on competition of SOD with Water Soluble Tetrazolium salt (WST-1) for reduction of $\mathrm{O}_{2}^{-}$. Briefly, $20 \mu \mathrm{L}$ of sample solution and $200 \mu \mathrm{L}$ of WST-1 solution were added and gently mixed. The reaction was initiated by adding $20 \mu \mathrm{L}$ of xanthine oxydase (XO) and xanthine mix (enzyme solution), which form the superoxide anion used by SOD and WST-1 (SOD Assay kit, SIGMA ALDRICH). Two blanks were performed by replacing sample solution with milliQ-water (background reduction of $\mathrm{O}_{2}^{-}$).

After incubation $\left(25^{\circ} \mathrm{C}\right.$ for $\left.20 \mathrm{~min}\right)$, the reduction of WST-1 by $\mathrm{O}_{2}^{-}$produces a yellowish formazan dye, the absorbance of which can be read at $450 \mathrm{~nm}$ with POLARstar Omega microplate reader (BMG LABTECH). As the rate of reduction of WST-1 by $\mathrm{O}_{2}^{-}$is linearly related to XO activity and is inhibited by SOD, SOD activity is calculated as an inhibition activity of this reaction. Subsequently, a standard inhibition curve was performed using SOD from bovine erythrocytes (SIGMA ALDRICH). SOD activities were expressed in units per $\mathrm{mg}$ of protein (U/mg); $1 \mathrm{U}$ of SOD being defined as the amount of enzyme inhibiting by $50 \%$ the reaction.

\section{2-7-Statistical analysis}

Correlation analysis between specific activities (PO and SOD) and protein contents were performed in order to assess the relation between those two variables. As we are interested in highlighting any monotonic relationship (either decreasing or increasing) and not only linear relationships, we used Spearman test of rank correlation.

Two-way split-plot analyses of variance (ANOVA) were conducted to determine differences in PO, SOD and protein contents according to the Injection Condition (fixed effect with three levels: SSW, LP2 and CECT4600 ${ }^{\mathrm{T}}$ ), Time p.i. (fixed effect with six levels: T0, 36 and 72 
hours, 7, 14 and 30 days p.i.) and their interaction (Injection $\mathrm{X}$ Time p.i.). The unit of replication was the tank where injected clams receiving the same injection condition were placed ( $\mathrm{n}=3$ tanks for each injection condition). The main plots were injection levels (SSW, LP2 and CECT4600 ${ }^{\mathrm{T}}$ ), subplots were sampling times (time p.i.). Three-way split-split-plot ANOVAs were used to determine differences in PO, SOD and protein contents upon injection condition, time p.i. and tissue. Characteristics of this three-way split-split-plot were similar to those of the two-way split-plot analysis except that sub-subplots were performed using tissue levels (hemolymph, EFs and mantle). The model used for these analyses was the linear model using the aov function in $\mathrm{R}$ that fits an ANOVA model. Where significant differences were obtained, a post-hoc analysis was carried out using Tukey's HSD test to determine which means were significantly different for main effects and interaction effects. Normality and homoscedasticity of residuals were assessed by graphical methods. Explained variables were all transformed using the $\log (\mathrm{x}+1)$ transformation in order to satisfy normality and homoscedasticity assumptions. All analyses were performed with R (version 2.15.3;) [39] and the "TukeyC" package [40].

\section{3-Results}

\section{3-1- Enzyme activities correlations with protein contents}

204 Prior to further investigation, enzyme specific activities were plotted as a function of protein content (Fig.1A-D). Those representations associated with non-zero correlation coefficients demonstrate particular correlations between specific activities and protein contents. In the mantle, PO specific activities (I.U.mg ${ }^{-1}$ ) (Fig.1A) are negatively correlated with protein content $\left(\rho=-0.98\right.$, p-value < 0.001). In hemolymph, PO and SOD specific activities $\left(\mathrm{U}^{\mathrm{m}} \mathrm{m}^{-1}\right)$ (Fig.1B and D) are both negatively correlated with protein contents (respectively for PO and SOD, $\rho=-0.52$, $\mathrm{p}$-value $<0.001$ and $\rho=-0.29$, $\mathrm{p}$-value $=0.001)$. Yet, specific data do not

211 truly represent PO and SOD activities as they superficially lower activities while protein 212 content rises. Thus, PO volumic activities (I.U.mL ${ }^{-1}$ ) in the mantle and hemolymph, and SOD 213 volumic activities (U.mL) in hemolymph were preferentially used. Conversely, in the mantle, 214 SOD specific activities (Fig.1.C) are positively correlated with protein contents $(\rho=0.43$, p215 value $<0.001)$. This allows for the direct use of SOD specific activity in the mantle. These 
216 results indicate that widely used specific activities are not always relevant, depending on the

217 considered tissue and enzyme.

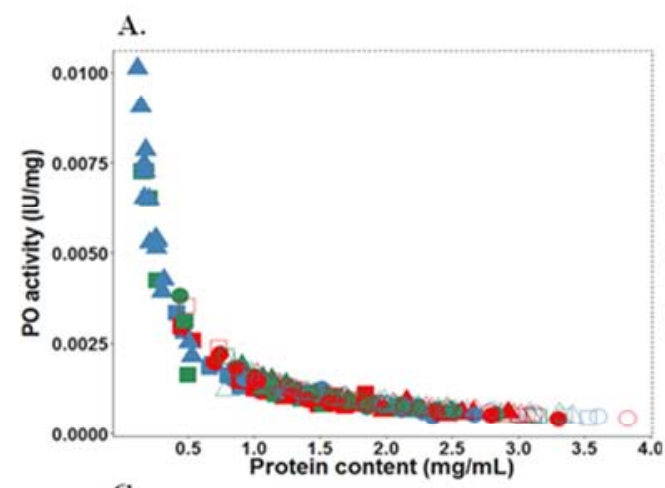

B.
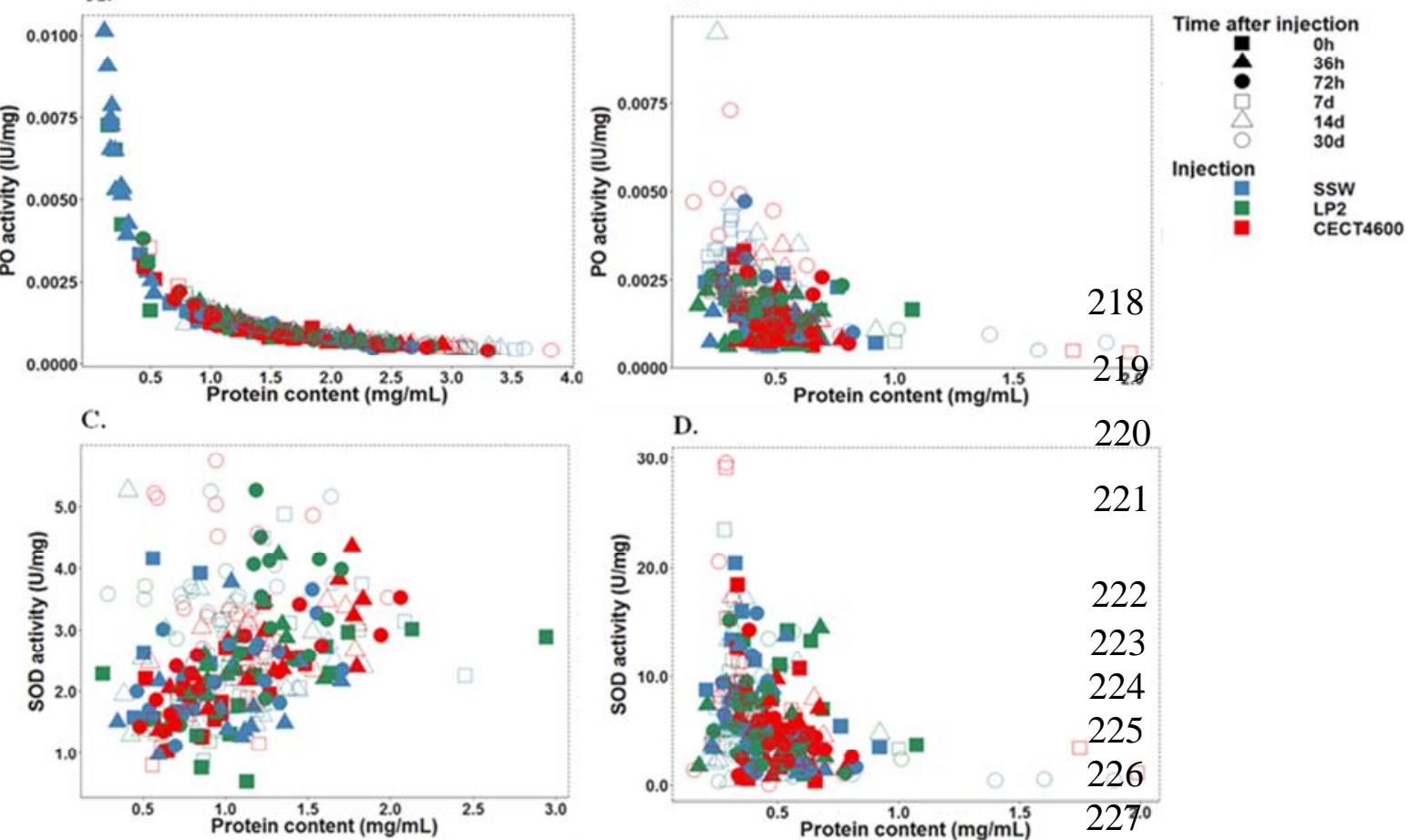

D.

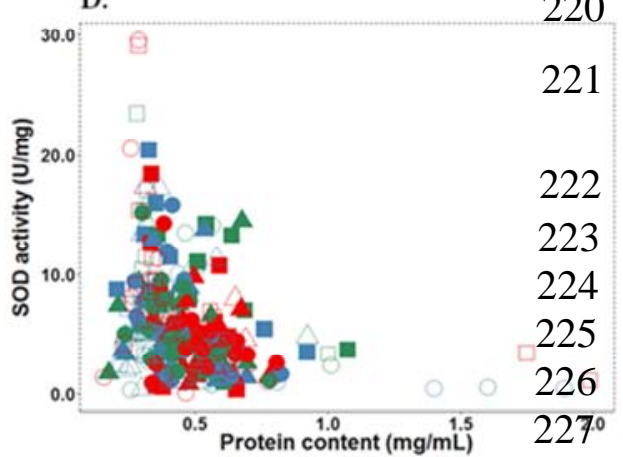

Fig. 1: PO specific activity and SOD specific activity as a function of protein content in the rmantle (A. and C.) and in hemolymph (B. and 23 . .) respectively. Note that axes do not cover the same variation range in all figures.

\section{$231 \quad 3-2$ Protein contents and enzymatic activities}

232 Results of statistical analyses are summarized in Tables 1, 2 and 3.

233 Protein contents varied as a function of injection $\times$ tissue $\times$ time interaction. In the mantle, a

234 significant time and injection interaction affected protein contents as it increased in

235 CECT $4600^{\mathrm{T}}$ - and LP2-challenged clams 36 hours p.i (Fig.2A). In hemolymph, there was no

236 significant time and injection interaction but protein contents were higher in LP2-challenged

237 and control clams 30 days p.i. (Fig.2B). In extrapallial fluids, there was no significant
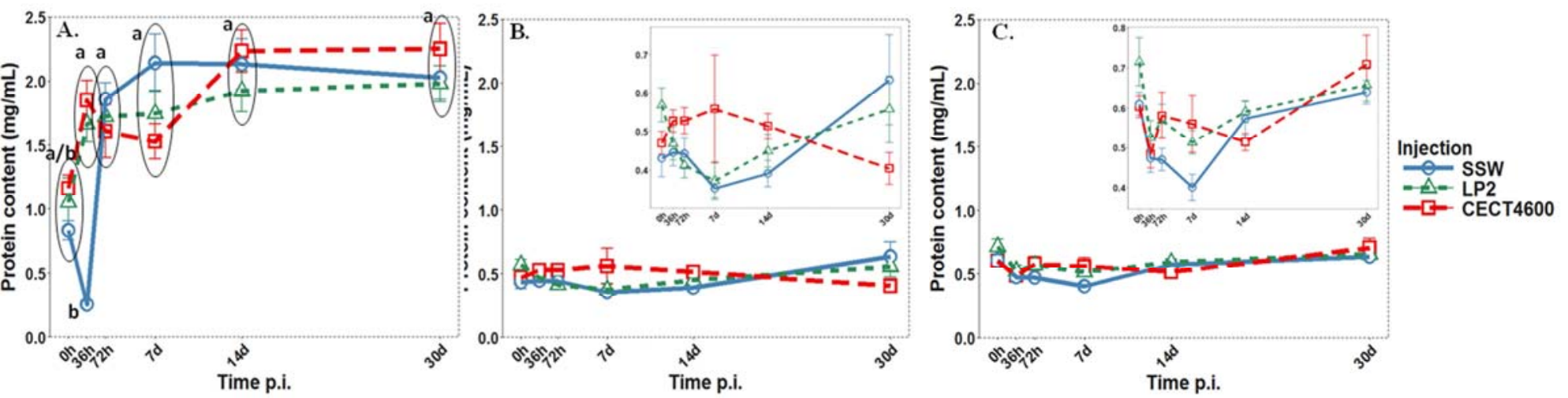

Fig. 2: Protein contents in the mantle (A), hemolymph (B with a zoom in Y value in the top right corner) and extrapallial fluids (C with a zoom in $\mathrm{Y}$ value in the top right corner) of $V$. philippinarum post-injection (p.i.) with $V$. tapetis (strains $\mathrm{CECT}_{4600^{\mathrm{T}}}$ and LP2) or Sterile Seawater (SSW). Error bars represent standard error. Letters indicate significant differences in protein contents upon injection between different groups and times (Split-plot ANOVA followed by post hoc Tukey's HSD test, $\alpha=0.05$ ). $\mathrm{N}=15$ 

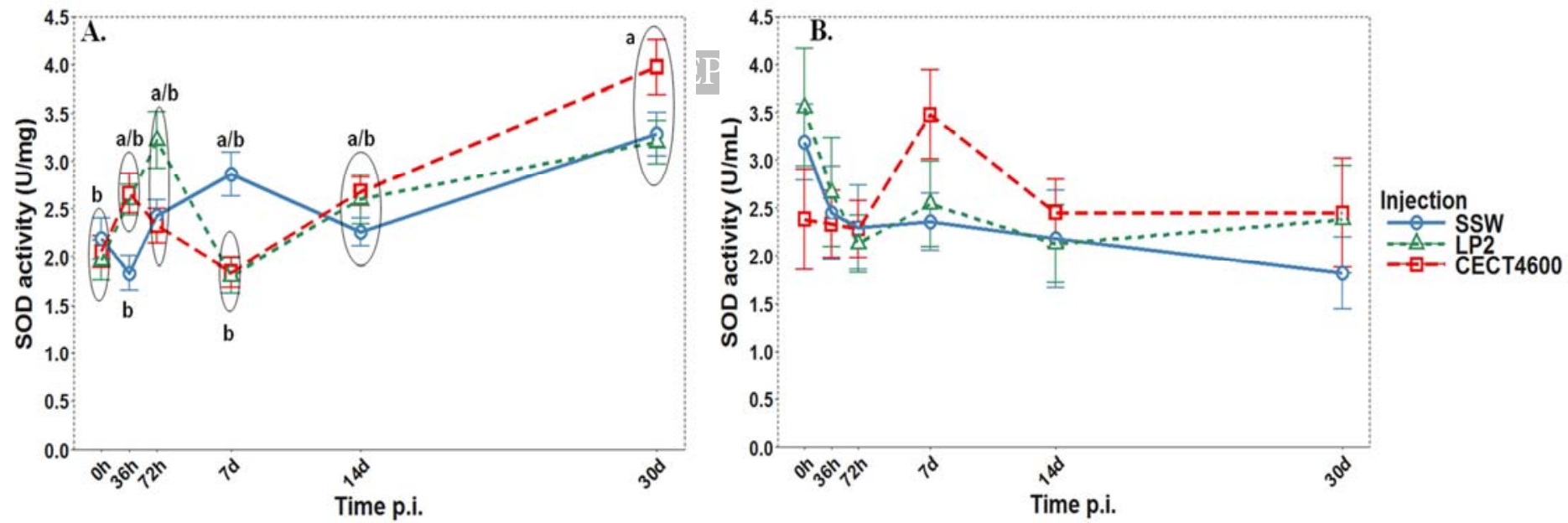

Fig. 46 6 OD activities in the mantle (A) and hemolymph (B) of $V$. philippinarum post-injection (p.i.) with V. tapetis (strains CEC294600 ${ }^{\mathrm{T}}$ and LP2) or Sterile Sea Water (SSW). Error bars represent standard error. Different letters indicate significant differences in SOD activity upon injection between groups and times (Split-plot ANOVA followed by post hoc Tukey's HSD test, $\alpha=0.04)$. $\mathrm{N}=15$ for each sampling time and injection combination.

265

266 
Table 1: Summary of the split-split plot three-way ANOVAs on the effect of injection condition, tissue sampled and time p.i. on protein contents, PO and SOD activity in the hemolymph of $V$. philippinarum

Source of variation

Main plot analysis

Injection

Error (tank)

Subplot analysis

Tissue

Injection $\times$ tissue

Error (tank $\times$ injection $\times$ tissue)

Sub-subplot analysis

Time

Injection $\times$ time

Tissue $\times$ time

Injection $\times$ tissue $\times$ time

Error (tank $\times$ injection $\times$ tissue $\times$ time)

Significant differences are indicated by $* * * \mathrm{p}<0.001 ; * *: 0.001<\mathrm{p}<0.01 ; *: 0.01<\mathrm{p}<0.05$; and no significant difference: N.S.

(ANOVA, $\alpha=0.05$ ).

267

268

Table 2: Summary of the split plot two-way ANOVAs on the effect of injection condition and time p.i. on protein contents, PO and SOD activity in the mantle of $V$. philippinarum

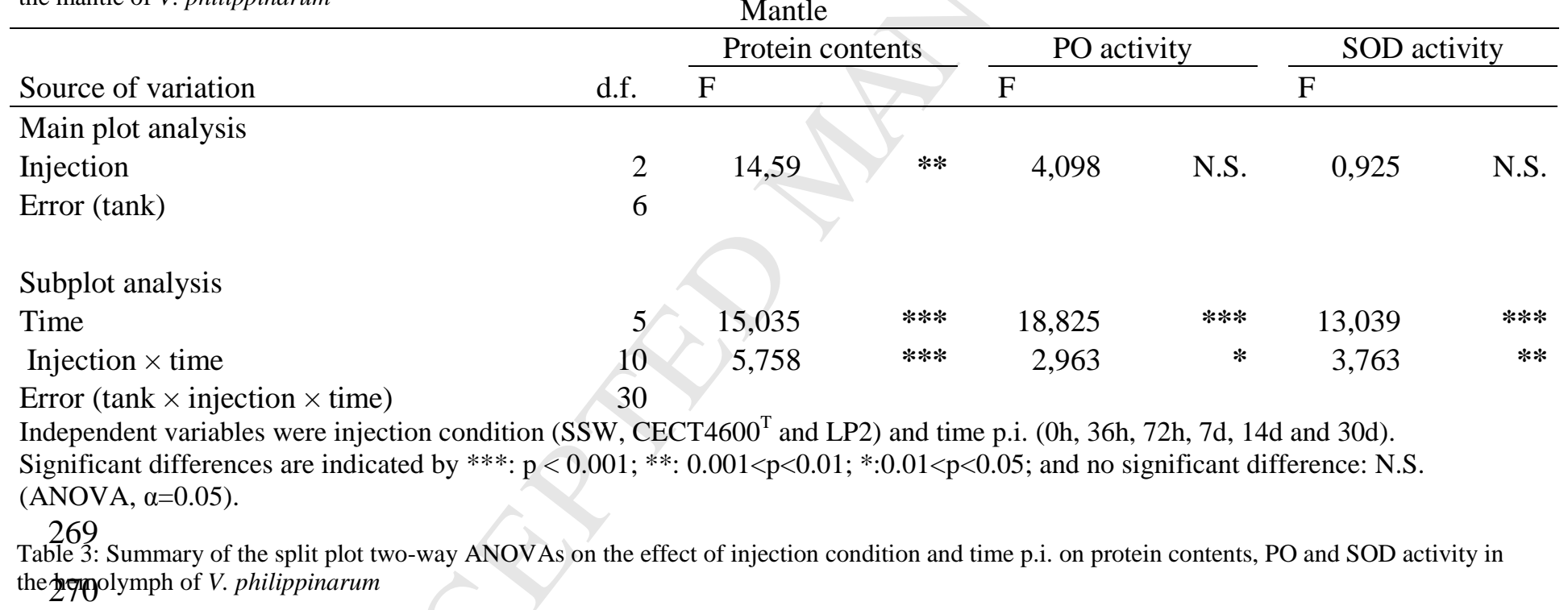

Hemolymph

Source of variation

Main plot analysis

Injection

Error (tank)

Subplot analysis

Time

Injection $\times$ time
13,005

4,276

12,707

5,209
$* * *$

$* * *$

****

$* * *$
12,266

1,804

10,248

3,279 $\begin{array}{cr}* * * & 7,649 \\ \text { N.S. } & 0,063\end{array}$

N.S.
N.S.

$* *$

\section{(}

$6 \quad 15,7 \quad 0,377 \quad$ N.S. $\quad 2,607 \quad$ N.S.

20

$\begin{array}{cr}* * * & 0,242 \\ \text { N.S. } & 1,821 \\ * * * & 5,591 \\ * * * & 2,584\end{array}$

N.S.

N.S.

$* * *$ 
Error $(\operatorname{tank} \times$ injection $\times$ time)

Independent variables were injection condition (SSW, CECT4600 and LP2) and time p.i. (0h, 36h, 72h, $7 \mathrm{~d}, 14 \mathrm{~d}$ and $30 \mathrm{~d})$.

Significant differences are indicated by $* * *: \mathrm{p}<0.001 ; * *: 0.001<\mathrm{p}<0.01 ; *: 0.01<\mathrm{p}<0.05$; and no significant difference: N.S. (ANOVA, $\alpha=0.05)$.

\section{4-Discussion}

\section{4-1 Time-inconsistency of the overall response in protein contents and enzymatic activities}

273 The present study reveals complex interactions between the time p.i., the injection condition 274 and the tissue considered. Indeed, kinetic responses of protein contents, PO and SOD 275 activities do not highlight a consistent pattern. Protein contents do not vary significantly with 276 injection and time p.i. in EFs and hemolymph serum while an increase, followed by 277 stabilization, is observed $36 \mathrm{~h}$ p.i. in the mantle. Yet, protein contents of fluids of $V$. 278 philippinarum were previously analyzed after an experimental challenge with $V$. tapetis in the pallial cavity and results pointed to a significant decrease of protein concentrations in EFs and hemolymph $[7,16]$. In our study, increases and decreases are both observed in SOD and PO activities depending on the tissue. Though these enzymes have never been monitored to our knowledge for such long periods of time in Manila clams challenged with $V$. tapetis. Additionally, control individuals exhibited variations in protein contents, in PO and SOD activities over experiment, revealing a response to SSW injection. These shifts were the results from manipulation of the clam especially during experimental injection. The handling effect on BRD development has been previously study in the Manila clam [41]. In our study, clams were removed from their tank 12 hours prior to treatment and injection done through the periostracal lamina causing a little hole within it. This way, injections allowed in particular, entrance of pallial water and so dilution of the extrapallial compartment content and thus induced a stress response in addition to the injected liquid itself. In our study, control animals, also stressed by the injection itself, must be regarded as control with respect to a

292 biotic stress which is the injection of bacteria. However, the shifts observed in these control animals should be kept in mind when considering the results for bacteria-injected animals.

294 Finally, another factor contributing to the inconsistency of the overall response of protein concentrations and enzymatic activities in this study was the inter-individual variability, particularly observed in fluids. Notwithstanding these inconsistencies during the experiment, when all factors considered, significant interactions are highlighted and are consistent with previous studies. 
300 A main result of this study is the differential PO and SOD changes between tissues. Activities

301 of these enzymes are tissue-dependent over all tested conditions (without infection and with 302 infection by two different strains). PO activity was higher in the mantle than in the serum, and 303 correlations between specific activities and protein contents were more marked for the mantle. 304 Differences in pattern between PO activities in various tissues are also known in the pacific 305 oyster, Crassostrea gigas [42].

306 In our study, correlations between SOD specific activities and protein contents in the mantle 307 and in hemolymph serum suggest two different profiles of SOD-like activity in these tissues.

308 These results are coherent with the distribution of the different SOD types and thus, their 309 putative different functions. In fact, there are three main types of SOD: intracellular cytosolic $310 \mathrm{Cu} / \mathrm{Zn}-\mathrm{SOD}$ (ic $\mathrm{Cu} / \mathrm{Zn}-\mathrm{SOD}$ ), intracellular mitochondrial Mn-SOD (ic Mn-SOD) and 311 extracellular $\mathrm{Cu} / \mathrm{Zn}-\mathrm{SOD}$ (EC-SOD) [43]. EC-SOD, which is the only SOD type present in 312 serum, could function differently from other SOD types present in the mantle in terms of 313 mechanism. To date, only ic $\mathrm{Cu} / \mathrm{Zn}-\mathrm{SOD}$ and ic Mn-SOD genes have been identified and 314 characterized in hemocytes and in the gills of $V$. philippinarum [33, 34]. Umasuthan and 315 collaborators [34] highlighted differential expression of the two SOD genes in terms of tissue 316 and in terms of SOD-type. Attempts to purify and characterize EC-SOD in bivalves were 317 performed but failed to find SOD activity associated with the purified proteins. Nevertheless, 318 few studies reported EC-SOD activity in bivalves. Immunoblot analyses of intracellular and 319 extracellular $\mathrm{Cu} / \mathrm{Zn}$-SODs showed that when the clam, Chamelea gallina was exposed to 320 anoxia or salinity stresses, EC-SOD in hemolymph was induced, whereas ic Cu/Zn-SOD 321 activity was reduced in hemocytes [44, 45]. These findings are in concordance with different 322 activity profiles of SODs depending on the considered tissue.

\section{4-3 Time- and tissue-dependent response of protein contents and enzymatic activities}

\section{4-3-1 A response governed by BRD development}

326 Another factor governing PO and SOD activity variations in our study was p.i. time. Results underlined an early response in the mantle and a later one in hemolymph that can be linked with BRD developmental stages. In natural conditions, the entry of the pathogen into the pallial space and the colonization of the periostracal lamina provokes alterations in 
periostracum secretions and disruption of the lamina, permitting $V$. tapetis to penetrate in the

331 Peripheral Extrapallial Fluids (PEFs) [46]. The normal deposition of periostracal lamina is seriously affected, resulting in a characteristic brown conchyolin deposit a few days after challenge with $V$. tapetis in the pallial fluids [4]. If the brown deposit leads to the occurrence of lesions, the bacteria penetrate the external epithelium of the mantle and proliferate in the tissues $[4,47]$. In our study, the injection was done directly in the peripheral extrapallial cavity (between the mantle and the shell), thus accelerating BRD development by bypassing the periostracal lamina. As this physical barrier was crossed, V. tapetis (strains CECT4600 ${ }^{\mathrm{T}}$ and LP2) was "helped" during the colonization phase in the extrapallial fluids (EFs). This could explain the response observed in the mantle at early times as this tissue is directly in contact with EFs. Maes [48] showed that V. tapetis inoculation in the clam pallial cavity induced faster mortalities than balneation exposure as the first physical barrier was ignored. More recently, Allam et al. [47] explored the role of the site of V. tapetis injection in Manila clam on BRD development. They found that mortalities reached $100 \%$ with animals injected in the adductor muscle and the central extrapallial space after making a hole in the shell (12 and 14days p.i. respectively) and highlighted the role of epithelium and pallial muscle attachment as external barriers. In our study, the concentration of $V$. tapetis used for inoculation was lower than that in Allam et al.'s study [47] (5.10 ${ }^{7}$ UFC/individual) and no damage was done to the shell due to extrapallial injections, explaining our low rates of mortalities (1.33\% over the 30 days of experiment, data not shown). Previous work demonstrated two key moments in the general immune response of Manila clam to $V$. tapetis pallial cavity injection, a first response within 24 hours p.i. and a second response at later times, 7 to 14 days p.i. [16-18].

\section{4-3-2 An early response associated with cellular factors in the mantle}

354 In the present study, protein contents, PO and SOD activities rise in the mantle between T0 and $72 \mathrm{~h}$ p.i. in CECT $4600^{\mathrm{T}}$ and LP2 injected clams. These rises could be explained by synthesis or release of proteins in infected zone to counter bacteria. PO activity in hemolymph cellular fraction of $C$. gigas has been shown to exhibit antibacterial activities against Vibrios shortly after challenges (between $0 \mathrm{~h}$ and $7 \mathrm{~h}$ p.i.) [49]. Additionally, Umasuthan and 
in the antibacterial response against $V$. tapetis by showing the time-dependence of this response. Moreover, after bacterial challenge, increase in SODs expression was observed within two days p.i. in bivalves and may be associated with scavenging ROS induced by bacteria $[33,34,50,51]$.

364 The early time responses observed in our study were previously detected in hemocytes of infected clams, resulting in an increase in total hemocytes count (THC) in the hemolymph and EFs [17, 18, 47]. In addition, Allam et al. [47] also observed a rise in phagocytic rates in EFs between 30 minutes and two hours p.i. when clams were injected in the extrapallial space with CTC-labeled $V$. tapetis. The enzymatic study of leucine-aminopeptidase (LAP) acitivity in hemolymph of $V$. tapetis-challenged clams showed similar results: a significant increase three days p.i. in the cellular fraction [17].

Taken together, these results suggest a first response at early times that is mainly cellular; high enzymatic levels in hemolymph cellular fractions were interpreted as an increase of enzyme synthesis in activated cells, triggered by $V$. tapetis injection [17].

\section{4-3-3 A later response associated with humoral factors in hemolymph and extrapallial fluids}

A later response was observed in our study, consisting of higher protein contents in the acellular fraction of hemolymph and EFs in V. tapetis injected-clams. Indeed, in hemolymph, protein concentrations were higher in CECT $4600^{\mathrm{T}}$-injected clams between 3 and 14 days p.i., in EFs they were higher in both CECT4600 ${ }^{\mathrm{T}}$ - and LP2-injected clams 7 days p.i.. These results are different from those observed by Allam \& Ford [14] who found increased protein concentrations in clams injected in the central extrapallial space three days p.i., irrespective of the treatment (i.e., bacteria or SSW). According to the authors, this augmentation was associated with the shell damage repair as injection was performed by making a hole in the central part of the shell [14]. In our study, peripheral extrapallial injection was done by inserting a needle between mantle and shell so that no damage occurred on the shell, explaining differences with the Allam \& Ford study. Augmentation of protein contents in fluids at later times was observed only in bacteria-injected clams, suggesting the synthesis or secretion of enzymes and peptides in extracellular compartments in order to counteract the bacteria [17]. Between 0 and 36 hours p.i. protein contents in EFs decreased in both bacterial and SSW injections. This result underlined a 'dilution-effect' post-injection as SSW or bacteria solution was added to the EFs during injection. 
391 In our study, PO activity in hemolymph supernatant rose between 7 and 14 days p.i. in

392 CECT $4600^{\mathrm{T}}$ - and LP2-injected clams and then stagnated until the end of experiment.

393 Presence of bacterial products, such as lipopolysaccharides or peptidoglycans, lead to

394 degranulation of semigranular and granular hemocytes containing proPO (the inactive form of

395 PO) [25]. After degranulation in the hemolymph, proPO is activated by proteolytic cleavage

396 by serine proteases, yielding active PO [22]. Thus the increase of PO activity in acellular

397 fraction we observed at later times could be associated with hemocyte degranulation induced

398 by $V$. tapetis challenge. This is also consistent with the results of Allam \& Ford [14] who

399 established a loss of granules in hemocytes after $V$. tapetis challenge in $V$. philippinarum.

400 In the present study, SOD activity in hemolymph supernatant rose to its maximum at day 7

401 p.i. in CECT4600 ${ }^{\mathrm{T}}$-injected clams and then decreased until the end of the experiment. EC-

402 SOD, is produced in hemocytes and secreted into extracellular fluids, where it represents the

403 major SOD-isoenzyme [52]. An EC-SOD gene was characterized in the bay scallop,

404 Argopecten irradians, and its expression in hemocytes was studied during the 48 hours

405 following a Vibrio anguillarum challenge [53]. The time-dependence of EC-SOD expression

406 in hemocytes was established with a peak of gene-expression at early times (12 hours p.i.) but

407 its activity in serum was not assessed. This difference in kinetic response of EC-SOD activity

408 and the expression of its associated gene might be due to several factors such as post-

409 transcriptional regulation, putative activation of the inactive form of EC-SOD or excretion of

410 it into the extracellular compartment [43]. To our knowledge, this is the first account of EC-

411 SOD activity in the acellular fraction of hemolymph in a bivalve challenged with Vibrio $s p$.,

412 and in order to confirm this hypothesis, it would be interesting to analyze gene expression of

413 SOD and PO.

414 In previous work, responses observed at later times in $V$. philippinarum challenged with $V$.

415 tapetis resulted in THC rising to its maximum at 7-14 days p.i. and decreasing after 14 days

416 p.i. $[16,17]$. Additionally, LAP activities in the cellular fraction of hemolymph reached their

417 peak 7 days p.i. [17] and lysozyme activity in this same fraction was significantly higher in 418 infected clams 14 and 28 days p.i. [16].

419 More generally, as hemolymph is a circulating fluid, the response observed at later times may 420 be explained by an "integration time" needed by the organism to counteract the infection and 421 also by the fact that the response is diluted across the whole organism. 
424 Our results suggest two different time- and tissue-dependent responses toward injections: a non-specific response related to a "bacteria-effect" and a specific response associated with CECT4600"s higher pathogenicity. The "bacteria-effect" or non-specific response was mainly observed in tissues that were directly injected, i.e. the mantle and EFs. Protein contents, PO and SOD activities were significantly higher in CECT4600 - and LP2challenged clams 36 hours p.i. in mantle and 7 days p.i. in EFs. These higher protein concentrations are a result of a synthesis and/or release of proteins in the affected tissues in order to counteract the bacteria.

432 In the mantle, PO and SOD activities were significantly higher in LP2-challenged clams than in CECT4600 ${ }^{\mathrm{T}}$ - and SSW-injected clams three days p.i. In hemolymph, protein contents, PO and SOD activity were higher in the case of CECT4600 ${ }^{\mathrm{T}}$-injection, 3-14 days p.i., 14 days p.i. and 7 days p.i. respectively. These specific biochemical responses point to the conclusion that there are differences between pathogenicities of the two V. tapetis strains. This is also in accordance with BRD stages (Conchyolin Deposit Stages) determined in clams 30 days p.i. as almost all CECT $4600^{\mathrm{T}}$-challenged individuals were symptomatic whereas $25 \%$ of LP2challenged ones were still asymptomatic (data not shown). Additionally, the most advanced symptoms were observed in CECT4600 ${ }^{\mathrm{T}}$-challenged clams and lower stages were found in LP2-challenged ones (data not shown).

442 To infect organisms and proliferate, Vibrios have to counter host defenses by different means 443 including phagocytosis inhibition, oxidative burst prevention and deregulation of signaling 444 pathways [54, 55]. In this single host experiment, interactions between host immune defenses and pathogen virulence factors depended on Vibrios pathogenicity [56]. This is why two $V$. tapetis strains were injected in $V$. philippinarum in this study: CECT4600 ${ }^{\mathrm{T}}$, isolated from

447 BRD-affected V. philippinarum [5, 57], and LP2, isolated from Symphodus melops in 1999 in 448 Norway [10]. The latter was previously considered as a non-pathogenic strain to Manila clam.

$449 V$. tapetis possess several virulence factors that could explain the pathogenicity of the two 450 strains used in this study. For example, adhesion to cells/tissues is accomplished through the 451 presence of pili in $V$. tapetis [5, 57] while the presence of smooth lipopolysaccharides 452 facilitates entry of the bacteria into the host's cells and tissues helping it avoid phagocytosis 453 [47]. Pathogenicity of V. tapetis, mainly studied in Manila clam hemocytes, results in a 
454

455

456

457

458

459

460

461

462

463

464

465

466

467

468

469

470

471

472

473

474

475

476

477

478

479

480

481

482

483

number of changes to clam cells, including cell rounding, vacuolizations and loss of adherence capacity $[12,14]$. Lopez-Cortez et al. [58] established that clam phagocytic activity was independent from pathogenicity degrees and host-range specificity of $V$. tapetis strain : soluble hemolymph proteins are not required for identification and internalization of the bacteria. These results support the non-specificity of immune responses toward the different strains we used in this study. Moreover, Choquet et al. [12] compared different strains of $V$. tapetis and classified LP2 strain as having a relatively low cytotoxic activity, whereas CECT $4600^{\mathrm{T}}$ strain is highly cytotoxic. This is consistent with our results and explains the specific response obtained toward the two strains tested. However, toxicity mechanisms remain poorly understood even if some factors have been identified.

\section{Conclusion}

This study highlights the modulation of two enzymes involved in immune response of $V$. philippinarum following bacterial infection in the extrapallial cavity, phenoloxidase and superoxide dismutase. The bacteria $V$. tapetis induces a time- and tissue-dependent response in the Manila clam. First, an early response occurs in the mantle, close to the injection site. This first response is associated with an increase of protein contents, as well as PO and SOD activity. Afterwards, a later response follows in the clams' fluids, resulting in an increase of PO activities and a decrease of SOD activities. These two times in immune response were also observed in previous work focusing on cellular and humoral components of $V$. philippinarum injected in the pallial cavity with V. tapetis [16-18]. Another main result of this study is the difference of pathogenicity between the two $V$. tapetis strains characterized by higher levels of enzymes' activities in hemolymph (between 7 and 30 days) and lower levels in the mantle (72h p.i.) in CECT4600 ${ }^{\mathrm{T}}$-injected clams. This work clearly illustrates the hostpathogen interaction and its consequences for these two particular enzymes in fixed environmental conditions. This interaction can be modulated by environmental factors, particularly temperature [59-61] and further studies should focus on the impact of environmental conditions on the Manila clam's response to V. tapetis and the pathogen's virulence. 
484

485

486

487

488

489

490

491

492

493

494

495

496

497

498

499

500

501

502

503

504

505

506

507

508

509

510

511

512

513

514

515

516

517

518

519

520

521

522

523

524

525

526

\section{Acknowledgements:}

This work was supported by the "Laboratoire d'Excellence" LabexMER (ANR-10-LABX-19) and co-funded by a grant from the French government under the program "Investissements d'Avenir".This work was also funded by University of Western Brittany. We would first like to thank the SATMAR company for providing the clams. We thank Adeline Bidault-Toffin, Nelly Le Goïc, Jérôme La Peyre, Romain Lavaud, Sébastien Artigaud, Malwenn Lassudrie, Camille Lacroix, Mélanie Mercier, Marc Long, and Mickael Perrigault for their help for the samplings during the experiments. Special thanks are addressed to Ewan Harney for linguistic revision.

1. Flassch J-P, Leborgne Y. Introduction in Europe, from 1972 to 1980, of the Japanese Manila clam (Tapes philippinarum) and the effects on aquaculture production and natural settlement. Introductions and Transfers of Aquatic species Selected papers from a Symposium Held in Halifax, Nova Scotia, 12-13 June 1990; 1992.

2. Paillard C, Maes P. Etiologie de la maladie de l'anneau brun chez Tapes philippinarum: pathogénicité d'un Vibrio sp. Comptes rendus de l'Académie des sciences Série 3, Sciences de la vie. 1990 310:15-20.

3. Paillard C. Rôle de l'environnement dans les interactions hôtes-pathogènes; développement d'un modèle de vibriose chez les bivalves. Habilitation à diriger des recherches (HDR), Université de Bretagne Occidentale, Brest. 2004.

4. Paillard C. A short-review of brown ring disease, a vibriosis affecting clams, Ruditapes philippinarum and Ruditapes decussatus. Aquatic Living Resources. 2004 17:46775.

5. Paillard C, Maes P, Oubella R. Brown ring disease in clams. Annual Review of Fish Diseases. 1994 4:219-40.

6. Borrego JJ, Castro D, Luque A, Paillard C, Maes P, Garcia MT, et al. Vibrio tapetis sp. nov., the causative agent of the brown ring disease affecting cultured clams. International journal of systematic bacteriology. 1996 46:480-4.

7. Allam B, Paillard C, Howard A, Le Pennec M. Isolation of the pathogen Vibrio tapetis and defense parameters in brown ring diseased Manila clams Ruditapes philippinarum cultivated in England. Diseases of aquatic organisms. 2000 41:105-13.

8. Reid HI, Duncan HL, Laidler LA, Hunter D, Birkbeck TH. Isolation of Vibrio tapetis from cultivated Atlantic halibut (Hippoglossus hippoglossus L.). Aquaculture. 2003 221:6574.

9. Castro D, Martinez-Manzanares E, Luque A, Fouz B, Moriñigo M, Borrego J, et al. Characterization of strains related to brown ring disease outbreaks in southwestern Spain. Diseases of aquatic organisms. 1992 14:229-36.

10. Jensen S, Samuelsen OB, Andersen K, Torkildsen L, Lambert C, Choquet G, et al. Characterization of strains of Vibrio splendidus and V. tapetis isolated from corkwing wrasse Symphodus melops suffering vibriosis. Diseases of aquatic organisms. 2003 53:25-31. 
11. Matsuyama T, Sakai T, Kiryu I, Yuassa K, Yasunobu H, Kawamura Y, et al. First isolation of Vibrio tapetis, the Etiological Agent of Brown Ring Disease (BRD), in Manila Clam Ruditapes philippinarum in Japan. Fish Pathology. 2010 45:77-9.

12. Choquet G, Soudant P, Lambert C, Nicolas J-L, Paillard C. Reduction of adhesion properties of Ruditapes philippinarum hemocytes exposed to Vibrio tapetis. Diseases of aquatic organisms. 2003 57:109-16.

13. Choquet G. Caractérisation et pathogénie des isolats de Vibrio tapetis, bactérie responsable de la maladie de l'anneau brun chez la palourde japonaise. Brest: Université de Bretagne Occidentale; 2004.

14. Allam B, Ford SE. Effects of the pathogenic Vibrio tapetis on defence factors of susceptible and non-susceptible bivalve species: I. Haemocyte changes following in vitro challenge. Fish \& shellfish immunology. 2006 20:374-83.

15. Jeffroy F, Paillard C. Involvement of nitric oxide in the in vitro interaction between Manila clam, Ruditapes philippinarum, hemocytes and the bacterium Vibrio tapetis. Fish \& shellfish immunology. 2011 31:1137-41.

16. Allam B, Paillard C, Auffret M. Alterations in Hemolymph and Extrapallial Fluid Parameters in the Manila Clam, Ruditapes philippinarum, Challenged with the Pathogen Vibrio tapetis. Journal of invertebrate pathology. 2000 76:63-9.

17. Oubella R, Paillard C, Maes P, Auffret M. Changes in Hemolymph Parameters in the Manila Clam Ruditapes philippinarum(Mollusca, Bivalvia) Following Bacterial Challenge. Journal of invertebrate pathology. 1994 64:33-8.

18. Oubella R, Maes P, Allam B, Paillard C, Auffret M. Selective induction of hemocytic response in Ruditapes philippinarum (Bivalvia) by different species of Vibrio (Bacteria). Aquatic Living Resources. 1996 9:137-43.

19. Allam B. Rôle des fluides extrapalléaux des bivalves dans la défense immunitaire: cas de la maladie de l'anneau brun chez la palourde d'élevage, Ruditapes philippinarum. Brest: Université de Bretagne Occidentale; 1998.

20. Beutler B. Innate immunity: an overview. Molecular immunology. 2004 40:845-59.

21. Chu F-LE. Defense mechanisms of marine bivalves. Recent advances in marine biotechnology. 2000 5:1e42.

22. Söderhäll K, Cerenius L. Role of the prophenoloxidase-activating system in invertebrate immunity. Current opinion in immunology. 1998 10:23-8.

23. Rodriguez-Lopez JN, Tudela J, Varon R, Garcia-Carmona F, Garcia-Canovas F. Analysis of a kinetic model for melanin biosynthesis pathway. Journal of Biological Chemistry. 1992 267:3801-10.

24. Aladaileh S, Rodney P, Nair SV, Raftos DA. Characterization of phenoloxidase activity in Sydney rock oysters (Saccostrea glomerata). Comparative Biochemistry and Physiology Part B: Biochemistry and Molecular Biology. 2007 148:470-80.

25. Cerenius L, Lee BL, Söderhäll K. The proPO-system: pros and cons for its role in invertebrate immunity. Trends in immunology. 2008 29:263-71.

26. Peters R, Raftos DA. The role of phenoloxidase suppression in QX disease outbreaks among Sydney rock oysters (Saccostrea glomerata). Aquaculture. 2003 223:29-39.

27. Newton K, Peters R, Raftos D. Phenoloxidase and QX disease resistance in Sydney rock oysters (Saccostrea glomerata). Developmental \& Comparative Immunology. 2004 28:565-9. 
28. Cong R, Sun W, Liu G, Fan T, Meng X, Yang L, et al. Purification and characterization of phenoloxidase from clam Ruditapes philippinarum. Fish \& shellfish immunology. 2005 18:61-70.

29. Le Bris C, Paillard C, Stiger-Pouvreau V, Guérard F. Laccase-like activity in the hemolymph of Venerupis philippinarum: Characterization and kinetic properties. Fish \& shellfish immunology. 2013 35:1804-12.

30. Labreuche Y, Soudant P, Gonçalves M, Lambert C, Nicolas J-L. Effects of extracellular products from the pathogenic Vibrio aestuarianus strain 01/32 on lethality and cellular immune responses of the oyster Crassostrea gigas. Developmental \& Comparative Immunology. 2006 30:367-79.

31. Buggé DM, Hégaret H, Wikfors GH, Allam B. Oxidative burst in hard clam (Mercenaria mercenaria) haemocytes. Fish \& shellfish immunology. 2007 23:188-96.

32. Fang FC. Antimicrobial reactive oxygen and nitrogen species: concepts and controversies. Nature Reviews Microbiology. 2004 2:820-32.

33. Li C, Sun H, Chen A, Ning X, Wu H, Qin S, et al. Identification and characterization of an intracellular $\mathrm{Cu}, \mathrm{Zn}$-superoxide dismutase (icCu/Zn-SOD) gene from clam Venerupis philippinarum. Fish \& shellfish immunology. 2010 28:499-503.

34. Umasuthan N, Bathige S, Revathy KS, Lee Y, Whang I, Choi CY, et al. A manganese superoxide dismutase (MnSOD) from Ruditapes philippinarum: Comparative structural-and expressional-analysis with copper/zinc superoxide dismutase ( $\mathrm{Cu} / \mathrm{ZnSOD})$ and biochemical analysis of its antioxidant activities. Fish \& shellfish immunology. 2012 33:753-65. 35. Paillard C, Maes P. The brown ring disease in the Manila clam, Ruditapes philippinarum I. Ultrastructural alterations of the periostracal lamina. Journal of invertebrate pathology. 1995 65:91-100.

36. Auffret M, Oubella R. Cytological and cytometric analysis of bivalve mollusc hemocytes. Techniques in fish immunology. 1995 4:55-63.

37. Corporeau C, Vanderplancke G, Boulais M, Suquet M, Quéré C, Boudry P, et al. Proteomic identification of quality factors for oocytes in the Pacific oyster Crassostrea gigas. Journal of proteomics. 2012 75:5554-63.

38. Bradford MM. A rapid and sensitive method for the quantitation of microgram quantities of protein utilizing the principle of protein-dye binding. Analytical biochemistry. 1976 72:248-54.

39. Team RC. R: A language and environment for statistical computing. In: Computing RFfS, editor. Vienna, Austria; 2014.

40. Faria JC, Jelihovschi EG, Allaman IB. Conventionnal Tukey Test. UESC. Ilheus, Brasil; 2014.

41. Jean F, Flye-Sainte-Marie J, Oudard C, Paillard C. Handling Enhances the Development of Signs of Brown Ring Disease in Ruditapes philippinarum. Journal of Shellfish Research. 2011 30:13-5.

42. Luna-Acosta A, Thomas-Guyon H, Amari M, Rosenfeld E, Bustamante P, FruitierArnaudin I. Differential tissue distribution and specificity of phenoloxidases from the Pacific oyster Crassostrea gigas. Comparative Biochemistry and Physiology Part B: Biochemistry and Molecular Biology. 2011 159:220-6.

43. Zelko IN, Mariani TJ, Folz RJ. Superoxide dismutase multigene family: a comparison of the CuZn-SOD (SOD1), Mn-SOD (SOD2), and EC-SOD (SOD3) gene structures, evolution, and expression. Free Radical Biology and Medicine. 2002 33:337-49. 
44. Monari M, Matozzo V, Foschi J, Marin MG, Cattani O. Exposure to anoxia of the clam, Chamelea gallina: II: Modulation of superoxide dismutase activity and expression in haemocytes. Journal of experimental marine biology and ecology. 2005 325:175-88. 45. Monari M, Matozzo V, Foschi J, Cattani O, Serrazanetti GP, Marin MG. Effects of high temperatures on functional responses of haemocytes in the clam Chamelea gallina. Fish \& shellfish immunology. 2007 22:98-114.

46. Allam B, Paillard C. Defense factors in clam extrapallial fluids. Diseases of aquatic organisms. 1998 33:123-8.

47. Allam B, Paillard C, Ford SE. Pathogenicity of Vibrio tapetis, the etiological agent of brown ring disease in clams. Dis Aquat Org. 2002 48:221-31.

48. Maes P. Pathologie bactérienne chez deux invertébrés marins d'intérêt commercial, Ruditapes philippinarum et Paracentrotus lividus. Brest: Université de Bretagne Occidentale; 1992.

49. Luna-Acosta A, Saulnier D, Pommier M, Haffner P, De Decker S, Renault T, et al. First evidence of a potential antibacterial activity involving a laccase-type enzyme of the phenoloxidase system in Pacific oyster Crassostrea gigas haemocytes. Fish \& shellfish immunology. 2011 31:795-800.

50. Umasuthan N, Saranya Revathy K, Lee Y, Whang I, Lee J. Mitochondrial thioredoxin2 from Manila clam (Ruditapes philippinarum) is a potent antioxidant enzyme involved in antibacterial response. Fish \& shellfish immunology. 2012 32:513-23.

51. Gao X, He C, Liu H, Li H, Zhu D, Cai S, et al. Intracellular Cu/Zn superoxide dismutase (Cu/Zn-SOD) from hard clam Meretrix meretrix: its cDNA cloning, mRNA expression and enzyme activity. Molecular biology reports. 2012 39:10713-22.

52. Marklund SL. Analysis of extracellular superoxide dismutase in tissue homogenates and extracellular fluids. Methods in enzymology. 1990 186:260-5.

53. Bao Y, Li L, Wu Q, Zhang G. Cloning, characterization, and expression analysis of extracellular copper/zinc superoxide dismutase gene from bay scallop Argopecten irradians. Fish \& shellfish immunology. 2009 27:17-25.

54. Sindermann CJ. Principal Diseases of Marine Fish and Shellfish: Diseases of Marine Fishes: Gulf Professional Publishing; 1990.

55. Pruzzo C, Gallo G, Canesi L. Persistence of vibrios in marine bivalves: the role of interactions with haemolymph components. Environmental microbiology. 2005 7:761-72. 56. Travers M-A, Le Bouffant R, Friedman CS, Buzin F, Cougard B, Huchette S, et al. Pathogenic Vibrio harveyi, in contrast to non-pathogenic strains, intervenes with the $\mathrm{p} 38$ MAPK pathway to avoid an abalone haemocyte immune response. Journal of cellular biochemistry. 2009 106:152-60.

57. Borrego JJ, Luque A, Castro D, Santamaría JA, Martínez-Manzanares E. Virulence factors of Vibrio P1, the causative agent of brown ring disease in the Manila clam, Ruditapes philippinarum. Aquatic Living Resources. 1996 9:125-36.

58. Lopez-Cortes L, Castro D, Navas JI, Borrego JJ. Phagocytic and chemotactic responses of manila and carpet shell clam haemocytes against Vibrio tapetis, the causative agent of brown ring disease. Fish \& shellfish immunology. 1999 9:543-55.

59. Paillard C, Allam B, Oubella R. Effect of temperature on defense parameters in Manila clam Ruditapes philippinarum challenged with Vibrio tapetis. Diseases of aquatic organisms. 2004 59:249-62.

60. Travers M-A, Basuyaux O, Le Goïc N, Huchette S, Nicolas J-L, Koken M, et al. Influence of temperature and spawning effort on Haliotis tuberculata mortalities caused by 
665 Vibrio harveyi: an example of emerging vibriosis linked to global warming. Global Change 666 Biology. 2009 15:1365-76.

667 61. Soudant P, E Chu F-L, Volety A. Host-parasite interactions: Marine bivalve molluscs 668 and protozoan parasites, Perkinsus species. Journal of invertebrate pathology. 2013 114:196669216.

670

671 